\title{
Iron Contamination: A Major Threat in Chhattisgarh, India
}

\author{
${ }^{1}$ Ritwik Harsh Jha and ${ }^{1,2 *}$ Santosh Kr. Karn \\ ${ }^{1}$ Department of Biotechnology, National Institute of Technology, Raipur, India \\ ${ }^{2}$ Key Laboratory of Marine Environmental Corrosion and Biofouling, Institute of Oceanology, \\ Chinese Academy of Sciences, Qingdao, China \\ santoshkarn@gmail.com
}

\begin{abstract}
Due to increase in urbanization, rapid industrialization and lack of proper management, has created a problem such as loss of biodiversity, affected environmental health as well as human health. Among the industry, mining is the prominent one because of a supplier of a raw material for various industries. Due to this ground this region affected more in terms environment as well human health.

Chhattisgarh is rich in various kinds of mineral and therefore mining is common here, especially iron mining affected this region much for the environment as well as to animal and human health. Due to the mining activities iron concentration has been increased in the surrounding soil and water and peoples using contaminated water for daily life purpose as well as for crop irrigation, therefore the metal deposited successively to different tropic level. The high concentration of iron into the body can form free radical which can lead to tissue damage and other neurodegenerative disease. Apart from this illness, accident and death of many people's are commonly observed. Hence an effort has been made to highlight this case study to pay more scientific attention, to find a suitable solution to minimize and resolve the problems.
\end{abstract}

Keywords: Iron danger; Chhattisgarh; Contamination; Mine tailing; Mutation; Adaption

\section{INTRODUCTION}

Chhattisgarh is the tribal-dominated provinces of central India by considering an area wise it is an $10^{\text {th }}$ largest provinces having population about 25.5 million. This province is the full of resource like electricity, steel, minerals, cement, coal, tin and iron ores production. All together we can say rich is diverse of minerals in the soil. Iron is the imperative mineral resource in Chhattisgarh. The production of iron ore is about 6 million tones every year (1). Iron ore deposits in Chhattisgarh are found in the following districts; Dantewara, Bastar, Kanker, Narainpur, Rajnandgaon, Durg and Kawardha mainly southwest part. Due to major mining activities in this area people's health, soil and water quality deteriorated significantly. Here mining activities has not assist or increased the income of local Chhattisgarhi people in its place they decreased the both worth and value of life and make them unhealthful because of the existence of contaminant/metal in the soil at high concentration. In May 2015 a new iron ore containing area is revealed in Kabirdham district (2). Simultaneously the environmental impact of mining activities can also be seen in this area like removal of top fertile layer of soil, cavity on the ground/surface source of groundwater contamination, biodiversity loss etc. Apart from this damage leakage of contaminated water affecting soil as well a health of local population.

\section{CASE PRESEnTAtion}

Here people's sole occupation is mining for living. They had to work in mines which are the source of daily bread and more than half of this area used in mining activities. These regions are famous for the high grade of iron ores and increased iron content. Mines are known for their prudent inorganic chemicals. Iron if present in excess amount is harmful becomes unfaithful to human and animal health. Sponge iron pollutants have a terrible impact on human health on inhalation or their vicinity leads to skin disorders. Thus it is known fact about metals that is in high concentration has negative effect to human and environmental health. Here people working in mines are prone to many kind of disorder and death can be observed due to their toxicity. Even many animal deaths can be observed in the surrounding forest due to dirking of the contaminated water released from the mining area. This occurs only due to the lack of complete precautionary measurement, proper mining, and inappropriate handling of mining waste. 


\section{DISCUSSION}

The consequence of metal toxicity can be recognized by observing different physiological process like absorption, metabolism. Because iron toxicity into the body can form free radical which can lead to tissue damage therefore it formation is strongly regulated. Problem of iron disorder are common to human and wide spectrum of disease has been recognized like from deficiency anemia and in excess causes neurodegenerative disease. A disorder hemochromatos is quite prevalent in the people exposed to mines characterized by excessive absorption of iron due to affected genes (3). Haemochromatosis is due to HFE-gene which residing on chromosome 6 and control the absorption process. Researcher found that two mutation $\mathrm{C} 282 \mathrm{Y}$ and $\mathrm{H} 63 \mathrm{D}$ in this genes. Resulting this is missense mutation that replaces the cysteine residue with a tyrosine residue at 282 positions. This occurred due to transition mutation at a position 845 in HFE-gene with adenine to guanine. Hetrozygous of either alleles don't show any clinical characteristic but can absorb more iron. Iron is important element for living organism because it participates in extensively in metabolic process like electron transport, oxygen transport, DNA synthesis etc. (4). Peoples of this region become habituated to drink polluted water as a result poor health and death can be frequently observed and there is chance that peoples might develop specific adaption to iron and may changes the particular gene because adaption drive changes in the genome. Evidences for this has proved by Schlebusch et al. (5) observed there was genetic adaptation in the peoples of arsenic contaminated region in Argentianin andes peoples and found single nucleotide polymorphisms (SNP) associated with AS3MT methyl transferase gene, signifying that AS3MT are main gene for arsenic metabolism in human. This research providing evidence that human population can develop adaption by changing specific gene even to toxic metal/chemicals. Therefore scientific attention is required for this specific area for organized study and finding efficient or suitable solution.

Currently the peoples of this region turn into used to for this situation like different kind accidents and casualty. Local governance always tries to hide the genuine circumstance concerning the public and environment health to maintain stable economy.

Thus it is suggested that urgent precautionary measures should be taken by the local government, community and non-governmental organization (NGO) so as to prevent contamination of groundwater resources by sewage and industrial discharges etc. and to encourage rainwater harvesting and recharging of groundwater resources by natural precipitations. Recently, WHO, (6) placed Chhattisgarh capital Raipur as the seventh most polluted city in the world. Hence the contamination level is increasing day to day at all the level because heavy industrialization. It is much often been observed and found about the death of many animals due to drinking of iron contaminated water in the forest area. Therefore it is essential to develop suitable remediation technique for tapped groundwater, by suitable removal technologies such as permeable reactive barriers, phytoremediation, biological treatment and electro-chemical treatment, to treat iron-contaminated soil and water.

This correspondence is based on social problem faced by local peoples whom I observed from my recent stay in Chhattisgarh from January 2015 to July 2016. Finally, I would like focus that increasing iron contamination in this area is of serious concern and number of case are increasing year by year because of contaminated water is used to grow and irrigate the vegetable and crop. Therefore it is essential to take precautionary measurement such as low cost domestic filtration system, pond sand filtration, rainwater harvesting and use of watershed management. As this area play major role to sheltered economy by contributing electricity/Power, Cement, Coal, steel production in this area. Therefore this state can be self sufficient in economy for the growth and development of the peoples.

\section{Conclusion}

This region required a systematic study by governmental as well non-governmental organization to focus on mining contamination, leakage, accident, peoples and animal health of this area. Because the number of affected people increased in the recent year and also immediately requisite to apply precautionary measurement, and find immediate requirement to peoples and search for suitable solutions.

\section{ACKNOWLEDGEMENT}

Authors are thankful to Department of Biotechnology, National Institute of Technology (NIT), Raipur for providing space and facility. 


\section{REFERENCES}

[1] Das Bhumika., Environmental impact due to iron ore mining in Chhattisgarh Recent Research Science Technology 6(1), 27-29 (2014).

[2] http://chhattisgarhmines.gov.in/iron-ore.htm

[3] Stephen A Gellera., Fernando PF de Campos. Hereditary hemochromatosis Autops Case Rep. 5,7-10 (2015).

[4] Abbaspour Nazanin., Hurrell Richard., Kelishadi Roya., Review on iron and its importance for human health. J. Res. Med. Sci.19, 164-174 (2014)

[5] Schlebusch, Carina M., Gattepaille, Lucie, M., Engstr€om, K., Vahter, M., Jakobsson, M., Broberg, K. Human adaptation to arsenic-rich environments. Mol. Biol. Evol. http://dx.doi.org/ 10.1093/ molbev/msv046. (2015).

[6] WHO. The Global Urban Ambient Air Pollution Database update released. Page 1-7, 2016. 